\title{
Self-Censorship and Associational Life in the Liberal Academy
}

\section{Emily Chamlee-Wright ${ }^{1}$}

Published online: 2 December 2019

(C) The Author(s) 2019

\begin{abstract}
Self-censorship is a well-documented phenomenon within the academy. Building from the works of Tocqueville, Mill, and Smith, this paper identifies sources of self-censorship within the academy, namely the values of intellectual abrasion and civility, that are associated with the liberal intellectual tradition. The resulting phenomenon of self-censorship, I argue, has both positive and negative effects on the quality of public and academic discourse. Given the dual nature of self-censorship, scholars seeking to make the morally upright choice of whether to self-censor or to speak up face both an epistemological and a moral challenge. I argue that in discussions of the "impartial spectator" and the virtue of self-command, Adam Smith's Theory of Moral Sentiments anticipates these challenges and lends guidance to the scholar who is sincerely committed to doing what is right when navigating associational life within the academy.
\end{abstract}

Keywords Self-censorship $\cdot$ Liberalism $\cdot$ Higher education $\cdot$ Academic discourse $\cdot$ Impartial spectator

\section{Introduction}

Self-censorship within the academy is a well-documented phenomenon. A survey conducted by the Gallup Organization and the Knight Foundation, for example, finds that $61 \%$ of students believe that their campus climate prevents students from expressing their views for fear of offending others. In its Campus Expression Survey, Heterodox Academy finds that rates of self-censorship are highest among students who do not conform to the politically progressive views of their peers. A survey conducted by the Foundation for Individual Rights in Education (FIRE) finds patterns similar to both studies.

Formal guarantees of academic freedom and due process are essential to ensuring that the vocal member of the academic community is protected against "hard forms of tyranny," such as expulsion or termination for advancing an unpopular point of view. But the findings of these surveys suggest that members of the academic community frequently experience what Glenn Loury (1994: 430) describes as a "velvet glove" tyranny in the form of social pressure to stay within the bounds of sanctioned

Emily Chamlee-Wright

echamleewright@ihs.gmu.edu

1 The Institute for Humane Studies at George Mason University, Vernon Smith Hall, 3434 Washington Blvd., Arlington, VA 22201, USA opinion. Tactics that intentionally or unintentionally chill academic speech range from mild social distancing, to ostracism, to over-zealous policing of procedural compliance, to calling out on social media, to accusations of professional impropriety (Kipnis 2017; Dreger 2016). The response to such tactics, or the threat that such tactics might be used, is often self-censorship (Bar-Tal 2017; Blackford 2019; Bromwich 2016; Glynn et al. 1997; Hayes et al. 2013; Hayes and Matthes 2017; Hyde and Ruth 2002; Loury 1994; Shields and Dunn 2016).

With increased frequency, we have heard from public intellectuals and scholars concerned that the "tyranny of opinion" has grown to the point that it represents an existential threat to liberalism itself. Building off of J.S. Mill, Russel Blackford (2019: 6), for example, argues that in our contemporary discourse we-even self-described academic liberals-have lost touch with Enlightenment liberalism, grounded within values such as "reason, liberty, free inquiry, individuality, originality, spontaneity, and creativity."

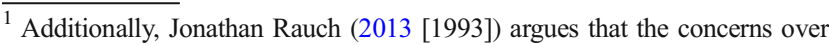
the harm that speech might inflict is stifling critical inquiry and the progress of liberal science. Sunstein (2003) argues that the corporate, legislative, and judicial processes degrade as a culture of candor and disclosure wanes. Sunstein argues further that the tendency toward extremism grows as dominant points of view go unchecked. Mark Lilla (2016) notes that the dominance of identity politics in academic discourse has made it increasingly difficult to have informed conversations across socio-economic and ideological divides and has moved us away from the foundations of liberalism. Alice Dreger (2016) ominously ends her book on academic freedom observing, "It is much too soon for us to end the Enlightenment."
} 
This warning - that liberalism itself hangs in the balanceis not new. Loury (1994) notes, for example, that McCarthyera politics, and the practices of totalitarian regimes around the globe have long given reason for concern. And the fates of Galileo and Socrates are apt reminders that the history of speaking one's mind in a politically contentious environment is long and fraught. But as some have noted, there's something different about the present challenge. Not only have we seen illiberal responses to the open expression of ideas, ${ }^{2}$ many of these responses seem to be coming from within the academy, which is particularly worrying given that the modern university and its associated values of academic freedom and intellectual openness are grounded in Enlightenment-era thought (Blackford 2019). Reports of increased self-censorship suggest that illiberalism in the academy is taking its toll on the quality of academic discourse, which has downstream effects on the quality of public discourse (Stevens et al. 2018).

Finding a remedy, however, is proving difficult. Because self-censorship is something that takes place inside the mind of the individual, it resists policy-oriented solutions (ChamleeWright 2018). Further, and as I argue below, because the phenomenon of self-censorship is tied to liberal ideals of the modern academy that we find attractive, sorting out when it is and is not appropriate to self-censor can be both epistemologically and morally challenging. Nonetheless, the liberal tradition does offer guidance. Adam Smith's Theory of Moral Sentiments (TMS), in particular, his concept of the impartial spectator and his meditations on self-command, provide a compass and general set of directions for navigating through this challenging terrain.

In the next section I review the warnings that Tocqueville and Mill issued with respect to the tyranny of opinion. In Section 3, I explore the roles that abrasion and civilityvalues central to the modern academy-play in fostering self-censorship, which in turn, has both positive and negative effects on the quality of public and academic discourse. In Section 4, I discuss guidance Smith's TMS offers the scholar sincerely committed to doing what is right with regard to selfcensorship. In Section 5, I offer concluding remarks and consider the implications Smith's insights have for the future of the liberal academy.

\section{Liberal Cautions Regarding the Tyranny of Opinion}

Alexis de Tocqueville (2010 [1835]) recognized that American democratic society has within it systemic forces that bend toward freedom, innovation, and human progress, on the one hand, and tyranny, stasis, and social regress on the other. The optimism and concern Tocqueville expressed shines a

\footnotetext{
$\overline{2}$ Scenes of protest from Yale, Evergreen State, Mizzou, and Middlebury have become common texts to anyone working within the American academy.
}

light on both the productive and corrosive power of associational life.

As Tocqueville observes, through associational life we solve all manner of social problems, great and small, and we fortify the foundation of a free society. This most quintessential American practice begins with intellectual and moral discourse. According to Tocqueville (2010 [1835]): 901),

As soon as some inhabitants of the United States have conceived of a sentiment or an idea that they want to bring about in the world, they seek each other out, and when they have found each other, they unite. From that moment, they are no longer isolated men, but a power that is seen from afar, and whose actions serve as an example; a power that speaks and to which you listen.

In other words, in a liberal democratic society, talk matters. The American propensity to engage in moral and intellectual discourse is the mother of robust civic engagement and sets in motion a bulwark against tyranny.

But Tocqueville also recognized that associational life has a dark side. As members of a majority with a dominant point of view, our fellow citizens can exercise a great power, a power that bends toward the velvet-gloved form of tyranny that Loury (1994) describes. Under democracy, Tocqueville (2010 [1835]: 418-19) observes that,

The master no longer says: You will think like me or die; he says: You are free not to think as I do; your life, your goods, everything remains with you; but from this day on you are a stranger among us. You will keep your privileges as a citizen, but they will become useless to you. If you aspire to be the choice of your fellow citizens, they will not choose you, and if you ask only for their esteem, they will still pretend to refuse it to you. You will remain among men, but you will lose your rights to humanity. When you approach your fellows, they will flee from you like an impure being. And those who believe in your innocence, even they will abandon you, for people would flee from them in turn. Go in peace; I spare your life, but I leave you a life worse than death.

Our fellow citizens represent a danger to our liberty, according to Tocqueville, not because they threaten us physically, but because they have the power to remove us from associational life (Hayes et al. 2013). Writing in the early nineteenth century, Tocqueville (2010 [1835]: 422) observed that Americans had lost the "virile candor, this manly independence of thought, that often distinguished Americans in former times." Some Americans, he noted, may hold views that diverge from the crowd, and they may confide those views in secret to the passing foreigner, but when "coming into the 
public square, they use another language." In Tocqueville's estimation, we fear so greatly the thought that our opinions will remove us from associational life that we respond by censoring our own thoughts and words, arresting the development of public discourse in the process. ${ }^{3}$

Building off of Tocqueville, Mill (1956 [1859]: 7) argues that the tyranny of opinion is potentially as dangerous as "the tyranny of the magistrate," concluding,

Protection, therefore, against the tyranny of the magistrate is not enough; there needs protection also against the tyranny of the prevailing opinion and feeling, against the tendency of society to impose, by means other than civil penalties, its own ideas and practices as rules of conduct on those who dissent from them; to fetter the development and, if possible, prevent the formation of any individuality not in harmony with its ways, and compel all characters to fashion themselves upon the model of its own. (Also cited in Blackford (2019: 15-16)).

When we lose the habit of engaging in intellectual challenge, Mill warns, truth claims are "understood lazily and unclearly" and the slow death of intellectual life begins. (See Blackford 2019: 39.)

But Mill does not make it clear what form this protection against the tyranny of the prevailing opinion should take other than eliminating laws prohibiting the expression of uncustomary views and simply leaving people be when they articulate such views. As with Tocqueville, Mill identifies a danger within associational life. Further, he argues that society should treat individuals with divergent views with a high degree of tolerance. ${ }^{4}$ But he offers no guidance for how the individual who holds such views should navigate this terrain if she is to maintain a place within the associational life of the community.

Developing such guidance is particularly important to an academic. No matter whether we live the "village life" of the small liberal arts college or the "big city cosmopolitanism" of a major university, we feel both the pleasures and pains of associational life. As scholars, we know that our job is to seek new knowledge. As such, we know that challenge and abrasion come with the territory. At the same time, we value the company of our peers from whom we learn, with whom we collaborate, and upon whom we depend for the rewards of

\footnotetext{
${ }^{3}$ Noelle-Neumann (1974) describes this phenomenon as a "spiral of silence," in which individuals assess the opinion landscape to determine whether their opinion matches or contrasts with majority opinion. To avoid ridicule and social isolation, individuals holding a minority opinion are more likely to refrain from expressing that opinion, further skewing the opinion landscape, which in turn accelerates the spiral of silence until only the few "core believers" are willing to express the minority point of view.

${ }^{4}$ Mill (1956 [1859]) made exceptions for cases of legitimate harm, but in his view, someone taking offense to an idea does not constitute harm.
}

academic life, namely our scholarly reputations. Arguably, navigating the inherent tensions of associational life well is the difference between a successful and an unsuccessful academic career. And though they may experience the tradeoffs differently than the professional scholar, the same tensions are present in the lives of undergraduates. Students know that intellectual challenge is essential to a successful college experience. At the same time, they recognize that a price is paid if they deviate too far from orthodox views of the modern academy. Just as professional scholars need the right principles to guide their steps through this terrain, so too do students, if they are to have a meaningful college experience.

Developing the appropriate guidance requires that we examine the sources of self-censorship within the academy. I am particularly interested in examining endogenous sources of self-censorship, which is to say, sources of self-censorship that are inherently bound up with the liberal ideals of the modern academy. Specifically, I will examine the principles of abrasion and civility, their role in the educational process, and how they lead to self-censorship that can have both positive and negative effects on the quality of academic and public discourse. Once this terrain is understood more fully, we are then in a better position to specify what sort of guidance is needed to navigate it well.

\section{Abrasion and Civility in Academic Life}

The modern academy is an artifact of liberalism. As Blackford (2019), Rauch (2013 [1993]), and others point out, the principle of intellectual openness, an underlying faith that rational argument pushes out the boundaries of knowledge and human well-being, that the open marketplace of ideas leads to good outcomes are all bound up in Enlightenment-era liberalism. The principles of abrasion and civility are part of that ethos. As I discuss below, these same principles generate self-censorship, which in turn, can have both salutary and corrosive effects on the quality of discourse.

\section{The Role of Abrasion in the Academy}

The value of abrasion in academic discourse is wellrecognized (Popper 1959, 1963). In On Liberty, Mill (1956 [1859]: 21) famously defends freedom of expression by observing that the collision of ideas benefits those who are correct, as they come away with a "clearer perception and livelier impression" of truth, and those who are mistaken, as they are given "the opportunity of exchanging error for truth." In other words, the abrasion of intellectual exchange sharpens our arguments and our minds. In Mill's view, therefore, we should, "be grateful to anyone who looks for weaknesses in received truths or mistakes in their application" (Blackford 2019: 39).

Heather Wood Ion (2015) notes that in addition to sharpening our intellects, campus life also provides a measure of 
social abrasion, something that is often seen as an essential part of the college experience. Wood Ion notes that exposure to diverse opinions, perspectives, and pedagogical methods creates friction that abrades prior expectations, unexamined assumptions, and the rough edges of lingering adolescence. A white student's first exposure to critical race theory, for example, can create both emotional as well as intellectual challenge. Arguably, the social and intellectual abrasion students experience is mirrored among the professoriate, especially as we engage across disciplines. Two decades of teaching alongside sociologists, for example, abraded some of the jagged edges that my economics training had left unchallenged and unrefined.

Abrasion has a particularly important role to play in difficult conversations, like those related to social identity. When we first learn the Pythagorean Theorem, new knowledge is conveyed. We may feel a sense of accomplishment or delight or boredom, but we generally don't feel anything like shame. The abrasion is slight. If the lesson were sandpaper, it would be 1000-grit. It's different, though, when the lesson points to something that we perhaps should have known, if only we had been more sensitive, or had a greater sense of humility, or "got out of our bubble" more. When our interlocutor says, "If you had grown up experiencing discrimination like I did, then you would likely see things differently," it may ring true. New knowledge is being conveyed here too, but unlike the Pythagorean Theorem lesson, the abrasive grit can feel rather rough. We may feel called out, not just for not knowing something, but for lacking sensitivity and humility. The phrase, "like I did," suggests that we may have unintentionally offended our conversation partner. Lack of intent to offend does not absolve us, as it is further evidence that we have missed something important that we should have known.

Conservative commentators often lament that rhetoric of this kind is designed to put some people (especially those with traditional forms of social privilege) in a conversational straightjacket. An alternative view is to see conversations like these as coaching sessions, in which peers, teachers, and colleagues help us to develop what Adam Smith describes as the vantage point of an "impartial spectator," the point of view that is gained by imagining how our conduct appears to a fairminded observer who stands at some distance from us (Otteson 2002). ${ }^{5}$ As we become better at this imaginary switching of places, we are better able to bring our thoughts, emotions, and actions in line with the sentiments of the broader society. This human capacity to align our sentiments with one another forms the basis for what eventually emerges as a self-regulating system of just conduct. ${ }^{6}$ As Smith

\footnotetext{
${ }^{5}$ For a discussion of the role distance plays in Smith's moral system, see Paganelli (2010).

${ }^{6}$ For a discussion of the self-regulating, market-like nature of Smith's moral system, see Otteson (2002).
}

observed in TMS, when we experience abrasion in the form of mild disapprobation - especially from our peers - we learn how to imagine ourselves in the shoes of a person who is different from us. We come to understand better how others understand and respond to their circumstances. In this process, we often come to appreciate better the degree of our own cluelessness to the circumstances of others. We might chafe a bit at the realization, but mild abrasion of this kind allows us to fill knowledge gaps between ourselves and others in different circumstances, and we become less clueless and more effective at speaking across social and cultural divides (Weinstein 2013). ${ }^{7}$

With that said, there is a point where abrasion ceases to be coaching and takes the form of punishment. When a majority (or vocal minority claiming moral authority) deploys the abrasion of associative life to punish rather than to enlighten or persuade, we approach a tipping point. The fact that there are relatively few incidents in which someone is publicly shamed for making a reasonable argument is less important than the fact that it is within the realm of possibilities that it might happen. Except for those seeking the limelight as provocateur, no one wants to suffer the fate of Brett Weinstein, the Evergreen State professor who was the target of an angry group of student protesters demanding his resignation for challenges he posed to the University's diversity programming. Any scholar who expects a reaction of this kind faces a strong incentive to self-censor.

In short, the ideal of the liberal academy invites abrasion, and calls us to submit to its temporary discomfort so that we might develop our intellect, resilience, and character. At the point that abrasion is weaponized, however, its effect is to shut down intellectual openness and the process that drives the growth of knowledge.

\section{The Role of Civility in the Academy}

While an educational environment requires abrasion, it also expects civility, not simply as a matter of politeness, but as a fundamental aspect of what it means to be a liberally educated person. Michael Oakeshott (1951), for example, observes that liberal learning is a social conversational process. But, in order to participate effectively, we need to be initiated into the art of conversation, acquiring the intellectual and moral habits associated with civility. These habits of mind allow us to recognize, in ourselves and our conversation partners, our underlying humanity. Colleges and universities are special places in Oakeshott's view, because they create the physical, learning, and social spaces in which we cultivate these habits. ${ }^{8}$

\footnotetext{
${ }^{7}$ For a discussion of pluralism within Smith's moral theory, see Weinstein (2013), in which he argues for the central role that education plays in supporting a pluralistic society.

${ }^{8}$ See also Shils (1997a, b).
} 
When we understand civility as acquiring the intellectual and moral habits appropriate to the great human conversation, we recognize that civility will involve some degree of selfcensorship. Civility and productive dialogue require that we think before we speak, which at times, means holding our tongues, withholding our thoughts until they are more fully formed, or until we find a way to express them in a manner that will reduce (to the degree possible) the risk of unnecessary offense. ${ }^{9}$ Though he does not use the phrase, Smith essentially says as much in TMS when he writes about the importance of tempering one's passions and moderating one's behavior to be in concordance with what the broader society will consider proper. What one says, and how one says it, are among those behaviors that may require tempering and moderating. Learning how to temper one's passions is not just a matter of politeness, it is essential to our development as moral beings.

Though essential to the health of the academy, civility also has the potential to degrade the quality of discourse, much as Tocqueville cautioned, leaving us too deferential to majority opinion. In particular, civility can undermine productive discourse when it is inappropriately understood to mean "don't rock the boat;" when making an unpopular argument is inand-of-itself considered to be an act of incivility. As Blackford (2019: 39) notes, Mill saw the potential danger in calls for civility if insistence on civility is used to justify speech suppression. "As [Mill] says, opponents will always view us as intemperate merely for expressing ourselves in a strong, forthright way - someone passionately committed to a rival view will likely feel this as an attack." ${ }^{\prime 0}$

And as concerned as he was with tempering our passions, Smith also considered truth seeking and willingness to act (and presumably, speak) on behalf of truth and justice to be a moral duty. Thus, the question of whether self-censorship is or is not a problem is context-dependent. In Smith's system, self-censorship may be exactly what is called for if that censoring is aimed at reigning in a passion, particularly an unsocial passion like anger that is too fiery for the circumstance at hand. But self-censorship is a significant problem in circumstances in which it leads the scholar to abandon her duty to contribute to rather than retreat from the truth-seeking enterprise. But saying this is not to suggest that the lines of demarcation are simple.

For example, while making an unpopular argument should not, in-and-of-itself, be considered an act of incivility, when combined with other factors, we may conclude otherwise. We all know this instinctively in our lives outside the academy. If we know that Aunt Ruth gets upset by our stance on a particular policy issue, we refrain from making that argument at her

\footnotetext{
${ }^{9}$ For a historical analysis of civility and acrimony in academic life, see Collins (2002).

${ }^{10}$ Blackford (2019) also notes, however, that Mill issues guidance on tone in some cases. For example, he counsels against stigmatizing someone as a bad or immoral person simply because he holds to a particular point of view.
}

Thanksgiving dinner table. The time, place, and purpose of the assembly is not a suitable setting for debate. Aunt Ruth's sensibilities do not, of course, set the standard in scholarly discourse. That said, there are norms that guide time, place, and purpose considerations, even in the academy. If our colleague's preferred argument is not germane to the topic at hand, we say to her (or at least think it in our heads), "now is not the right time to pursue the point." If an argument has been raised, refuted, and is widely considered a settled matter by relevant experts, we consider it a breach of civility if a colleague persists in his attempts to argue otherwise, especially if the purpose of the gathering is to move the conversation forward rather than revisit matters already considered settled. Given the scarcity of time and attention bandwidth, such norms serve us in our efforts to make intellectual progress.

But the parameters of civility such as the "germaneness test" and the "settled matter test" can be misapplied, crowding out or disallowing arguments simply because we don't like them. ${ }^{11}$ When an admonition has the weight of the majority (or a vocal minority claiming moral authority) behind it, Tocqueville's "manly independence of thought" can easily slip away and something like "group-think" may set in. The title of Alice Dreger's book Galileo's Middle Finger makes the point well. Making an argument that aims at truth, but fails to align with a preferred (dominant) political or ideological message, can lead the group, particularly one bound by a sense that they have the moral high-ground, to cast out the heretic. A common rhetorical device of groups seeking ideological purity is to bypass counterargument altogether by naming the conclusion they disfavor as blasphemy. According to this logic, it follows that the purveyor of blasphemy is evil, and therefore, not worthy of a hearing. Taking the logic one step further, such heretics must be punished, so that they do not continue to spread their lies. Further still, they must be expelled from the community so that they do not poison the minds of others, particularly young and impressionable people under their tutelage. While scholars seek distinction, most of us would prefer to avoid the treatment reserved for heretics, and we face a strong incentive to adjust our behavior accordingly. Not a single rule of formal censorship is required, in other words, for a good deal of censorship to occur.

It is tempting to say to ourselves that we can rise above such tactics - that we will not be among those who will cast out the Galileos in our midst. But making this claim is trickier than it might seem, especially if we believe that it is sometimes appropriate to use language to admonish, punish, and withdraw approbation. ${ }^{12}$ The power of language to withdraw

\footnotetext{
$\overline{11}$ For a discussion of the value of "devil's advocate" arguments, and the value of revisiting issues that are widely considered a settled matter, see Courtland (forthcoming).

${ }^{12}$ From an early age we learn from our parents, siblings, peers, teachers, coaches, and other adults that bestowing and withdrawing approbation is a core function of language.
} 
social approval is critical to associative life, and it is part of what gives freely associating people the ability to safeguard liberty. As Strossen (2018) argues, for example, we don't need the state to punish racist or misogynist speech because we can do that on our own by withdrawing our approval. It is wellwithin the bounds of liberal principles to deploy language to register disapproval of those who, for example, deny the inherent dignity of a particular group of people. But the fact that withdrawing social approval is sometimes justified makes the associative life wicket all the stickier. It's often difficult to know when and where to stop. And for those who value the benefits of associational life, which includes the affection of friends and colleagues and professional standing and reputation, it is also difficult to know when it is that we are engaging professionally and civilly and when we are simply caving in to the pressure to conform. It is this dual effect of self-censorship - that it sometimes leads to social harmony and mutual respect, and that it sometimes leads us away from candor and truth - that makes it particularly difficult to navigate.

When we consider the importance of humility, the navigation becomes even more difficult. It may be tempting, for example, to fancy ourselves as being Galileo-like, immune from social pressures that would have us self-censor. But such a stance creates a tension between ironclad confidence in one's own ideas, no matter what others say, and a commitment to epistemic humility. When so many disagree with us, might that give us pause? Might we withhold our point of view, at least until we gain a sense from others that we are on the right track? As with civility, it is hard to know where appropriate humility and caution ends and inappropriate caving to social pressure begins. Again, some degree of self-censorship is a good thing if we hope to avoid the corruptions of arrogance. Our reasonable and desirable commitments to civility and epistemic humility, however, may in some moments make us complicit in a social dynamic that leads the academy away from the fearless pursuit of truth.

In short, abrasion and civility can both be sources of selfcensorship, which in turn, fosters both positive outcomes (namely, mutual sympathy and respect) and negative outcomes (namely, reluctance to engage in the open exchange of ideas). Because scholars are enculturated into the liberal norms of abrasion and civility - through undergraduate and graduate study and the intensive intellectual mentoring of research assistantships and the dissertation process-we carry these values with us into the culture of the academy, and enculturate the next generation to adopt these same intellectual habits. We are expected, in our lives as students, researchers, teachers, and colleagues, to challenge (to abrade) one another and to submit to such abrasion. We are expected to engage in the grand conversations of our discipline and the broader academy with civility, which will sometimes require that we stop and reconsider what we are about to say and how we will say it - as this is essential to the health of the conversation. But these same norms can also tend toward weaponized abrasion, excessive deference, and conformity that shuts down the free and open exchange of ideas.

Self-censorship, then, is neither inherently bad or good. It is, rather, the choices that scholars make under specific circumstances that determine self-censorship's effect on the quality of discourse. Scholars therefore need guidance as to when it is and is not appropriate to self-censor. As I argue below, responding appropriately is both an epistemological and moral challenge. Smith's discussions of the impartial spectator and the virtue of self-command anticipate both aspects of this challenge.

\section{Navigating the Challenge}

The scholar ${ }^{13}$ who sincerely seeks to do what is right - that is, to speak up when it serves the truth-seeking enterprise, without blithely disregarding the norms of associational life within the academy - faces two distinct but related problems.

Problem 1: "How do I know whether self-censorship is appropriate or not?"

Problem 2: "Once I know which course of action is proper, how do I summon the appropriate virtue(s) to do what is right?"

Problem 1 presents an epistemological challenge. The scholar who is sincerely motivated to do what is right with respect to self-censorship must navigate the epistemological terrain of knowing when to pay heed to the signals and pressures emanating from associational life and when to ignore those signals and pressures. If the scholar's impulse is to restrain herself from speaking, how does she determine the difference between civility (professionalism), on the one hand, and cowardice (conformity) on the other? If the scholar's impulse is to speak out, how does she determine the difference between being appropriately assertive in the name of truth seeking, on the one hand, and avoiding the perils of arrogance, on the other? A straight-forward demand that one must exercise the intestinal fortitude to "do the right thing," therefore, is largely unhelpful, as it assumes away the epistemological dimensions of the challenge.

Problem 2 presents a moral challenge. In some situations the appropriate virtue is something like emotional restraint. For example, in the face of injustice - when one has been wrongfully accused, or made the target of weaponized abrasion, the challenge may be to refrain from saying what immediately springs to mind. In other situations, the appropriate virtue is something like bravery - to speak up even when others are likely to disapprove and perhaps condemn. In many

\footnotetext{
${ }^{13}$ Though the pressures and incentives to self-censor weigh differently on undergraduate students, young scholars, and senior scholars, they all face, more or less, the same epistemological and moral challenges that I describe below. For that reason, I will use the same term, "scholar," to refer to all of them.
} 
circumstances, Problem 2 is temporally bound up with Problem 1 in that the scholar has to summon the appropriate virtue in the same moment that she is faced with the task of figuring out what the right course of action is. Other circumstances allow for more deliberate thought. And while the level of challenge can vary from slight to significant, in all cases, the scholar is faced with the dual task of sorting (Problem 1) and summoning (Problem 2).

\section{The Impartial Spectator's Connection to and Independence from Associational Life}

In variations of Problem 1 the fundamental difficulty lies in interpreting and knowing what the appropriate response is to the feedback we receive (or imagine we might receive) from our academic colleagues, be they the general academic public or specific people we know. Much of the feedback a scholar encounters is straightforward in the sense that it is aimed at error correction, identifying gaps in logic, or weaknesses in the supporting evidence. Such feedback may be routine or withering, but it is generally not the subject of contemporary concerns regarding self-censorship, as it is an expected and necessary part of intellectual discourse. What tends to be of concern is feedback, actual or imagined, that warns in some way that a scholar's argument or rhetorical stance is at odds with the socially approved point of view. Such feedback may be in the mode of coaching, or mild admonition, or accusation. Feedback of this kind may be bound up with standard forms of intellectual critique, which can make it difficult to differentiate thoughtful challenge from knee-jerk ideological reaction. Making the interpretive challenge even more difficult is the fact that there may be wisdom in the admonitions and accusations, even if they are ideologically driven.

In an ideal world, we would attend to feedback that makes our argument better and/or allows us to communicate more effectively. This may mean holding our tongue until we have an opportunity to think it through or until we find a way to communicate our ideas that won't unnecessarily alienate potential conversation partners. Correspondingly, in an ideal world we would set aside feedback that, if heeded, would lead us away from the effort to seek truth. Given the complicated terrain, we need a "compass" that helps us sort through feedback signals effectively. In his discussions of the impartial spectator Smith anticipates the need for such a compass. Further, in his meditations on self-command, Smith identifies the virtues the impartial spectator will draw upon to follow through once the right course of action has been determined.
As Smith describes it, human beings develop an impartial spectator through experience. ${ }^{14}$ We learn our first lessons at an early age, when we venture beyond the (partial) gaze of close kin to the company of (less-partial) friends. Whereas mother and father may be inclined to indulge misbehavior, our playfellows will not be so forgiving. We will feel the abrasive sting of their disapprobation if we violate the informal norms of play or act inappropriately. We also experience the warm glow of approval when we measure up in their eyes. And we begin a practice of examining "our own passions and conduct, and to consider how these must appear to them, by considering how they would appear to us if in their situation" (TMS: 206). In this way, we learn to align our thoughts, emotions, and actions with the sentiments of the broader society.

The scholar sincere in her desire to make the right judgment, therefore, will not entirely disregard the likely response from the general academic public. In keeping with Smith, she will endeavor to view her own conduct and passions "with the eyes of other people, or as other people are likely to view them" (TMS 203-4). Smith's use of the phrase "other people" is noteworthy. It suggests that gauging general opinion has value. Checking our conduct (or prospective conduct) against how "other people" will view it helps to assure that we are adhering to rules we acquire through associational life, general rules concerning what is fit and proper. Basic rules of civility fall into this category. If our temper is out of line with what would be a proper response to a situation, our observance and respect for general rules of just conduct "checks the impetuosity of [our] passions, and helps [us] to correct the too partial views which self-love might otherwise suggest of what was proper to be done in [our] situation" (TMS 266-7). ${ }^{15}$

Consider, for example, a scholar engaged in heated exchange with a fellow panelist before a live audience of their academic peers. Assume further that the scholar's interlocutor is engaging in an uncivil manner. In such circumstances, aspects of both Problem 1 ("What is the proper response?") and

\footnotetext{
${ }^{14}$ Klein et al. (2018) argue that Smith sometimes describes the impartial spectator as "the impartial spectator," as in an ideal entity with super-human knowledge and moral judgment. At other times, Smith's impartial spectator is described as a representative of the impartial spectator. The "man within the breast" language, they argue, suggests this latter version - an imagined construct that imperfectly stands in for the ideal. I find the "an impartial spectator" language helpful when describing the developmental nature of acquiring moral judgment. With that said, "the impartial spectator" is nonetheless conceptually useful as well - in the way that True North is conceptually useful in guiding a physical journey-regardless of whether we ever actually achieve it or not.

15 It is worth noting that Mill and Smith differ in their view of custom and the general rules that arise from it. Whereas Smith sees the habitual adherence to general rules of just conduct as the foundation for a self-regulating moral system, Mill (1956 [1859]: 9) warns that the "magical influence of custom" keeps people from thinking independently about the pros and cons associated with general rules. Mill writes, "I do not mean that they choose what is customary, in preference to what suites their own inclination. It does not occur to them to have any inclination, except for what is customary. Thus the mind itself is bowed to the yoke: even in what people do for pleasure, conformity is the first thing thought of; they like in crowds; they exercise choice only among things commonly done" (Mill 1956 [1859]: 61).
} 
Problem 2 ("How do I keep my cool and act appropriately?") are present. In the heat of the moment, a scholar may be tempted to suspend the rules of propriety to which she normally adheres. The wise scholar will check her rhetoric and tone, not against her interlocutor's likely response, but against what the audience - the general academic public - will deem proper. In doing so, she reminds herself to pay heed to the general rules "concerning what is fit and proper to be done in our particular situation" (TMS, 266). Those general rules serve as a cognitive shortcut when sorting proper from improper responses, (i.e., Problem 1). If a scholar's prospective speech is not in alignment with the basic rules of civility, consulting the imagined general academic public also helps her to override her immediate emotional response and summon the restraint that the moment requires, (i.e., Problem 2).

While paying close attention to the norms of associational life is an important step in ensuring the propriety of our conduct, some situations require that we are also able to put intellectual and emotional distance between ourselves and the general academic public. Recalling Tocqueville's and Mill's cautions, there will be circumstances in which the norms of associational life are less about upholding general rules of civility, and more about conforming to the dominant point of view, i.e., not rocking the intellectual boat. And it is in such circumstance that an impartial spectator may achieve a more advanced developmental stage if we are able to recognize that the general public is not always fair in its judgement. Smith notes, for example, that the public often fails to offer praise even when one's conduct has been praiseworthy. While disappointing, small injustices like these are valuable. Through them, we come to learn the important distinction between a love of praise (i.e., chasing the affection of the public), and a love of doing that which is worthy of praise (i.e., earning the respect of the impartial judge). The former is vanity. The latter is the source of virtue.

When we suspect that the public may be rendering an uninformed or less-than-fair assessment of our conduct, it behooves us to imagine the most impartial of spectators. "We endeavor to examine our own conduct as we imagine any other fair and impartial spectator would imagine it" (TMS 204). It's not, in other words, just any spectator with whom we switch places to gain the distance we need to assess the propriety of our conduct. Nor is it simply "other people"- the broader public or the academic public - with whom we make the switch. The switch we need to make is with a depersonalized, well-informed, and impartial judge. As we acquire experience at deploying this imagined impartial spectator, we acquire the "habit of conceiving" as natural and proper the approbation that should come from praiseworthy conduct, even if "admirers may neither be very numerous nor very loud in their applauses" (TMS 409).

This practice gains for us an intellectual independence from the general academic public required to address Problem 1. If, in the name of truth-seeking, the scholar challenges the dominant point of view despite the fact that she will likely bear a social or professional cost, the imagined impartial spectator will approve. If, on the other hand, the scholar simply parrots the dominant point of view or refrains from speaking what she believes to be true out of fear, i.e., she is chasing praise and/or avoiding blame, such conduct will not earn the approval of such a spectator. The imagined impartial spectator's approval and disapproval is the guidance the scholar needs to determine whether greater intellectual distance from the general academic public is required.

Further, a well-developed impartial spectator encourages the emotional independence a scholar may need to address Problem 2. By repeatedly invoking that spectator, the scholar trains her mind to consider the impartial spectator, not the general academic public, as her most trusted counsel. Others might affirm and strengthen her sense that her actions have been admirable, but praise from others will not substitute for the judgment of the impartial spectator if she knows that her conduct has not been truly praiseworthy. ${ }^{16}$ Nor will censure from the general academic public diminish her estimation of her conduct if she knows that it has been worthy of praise.

\section{Sorting and Summoning in More Complex Terrain}

To this point, it may seem that the insight the imagined impartial spectator lends is no deeper than the "kitchen table wisdom" our elders conveyed in our formative years: "keep a civil tongue," "don't speak out of anger," "have the courage of your convictions," and so on. But to the extent that we find advice like this to be obvious, it is because our impartial spectator is already well-practiced through repeated experience. Smith (TMS 246) observed that we acquire self-command through the "bustle of business in the world." Not unlike accomplished athletes, through countless "reps," we develop something akin to "muscle memory," a kind of auto-response that allows us to perform something well without having to think it through. In commonplace situations, this muscle memory allows us to make good judgements and summon the appropriate virtues somewhat automatically. ${ }^{17}$ It is through repeated commonplace experiences that we train the mind for more difficult challenges.

One of the more difficult circumstances scholars frequently face occurs when the imagined switching in perspectives is a heavier-than-normal lift. Any scholar identifying and analyzing social and cultural patterns, for example, bumps up against the fact that their knowledge of the subject they study is

\footnotetext{
$\overline{16}$ In fact, according to Smith, we come to regard praise for conduct that is not truly praiseworthy as being "more mortifying than any censure" (TMS 209), and any positive feeling that comes from misplaced praise "the effect only of the most contemptable vanity" (TMS 213).

${ }^{17}$ In the Aristotelian philosophical tradition, the consistent practice of particular virtues results in those virtues becoming 'second nature.'
} 
shaped - aided and inhibited — by their own social and cultural experience. ${ }^{18}$ This can make the switching process lessthan-automatic. Feedback from the general academic public and specific colleagues is often aimed at closing knowledge gaps brought on by the perspectival nature of knowledge. A heterosexual researcher studying a program's effectiveness on reducing teenage homelessness, for example, may not think to ask how his results might change if he were to oversample for LGBTQ+ teens. When a researcher takes a challenge of this kind seriously, he shifts his perspective, and may see the same phenomenon anew, from the vantage point of someone who experiences that phenomenon differently. ${ }^{19}$ He may recognize, for example, that solutions that work for heterosexual teens are less effective within the LGBTQ+ teen population, as they are more likely to have been ostracized by their families. The switching of vantage points, in other words, has the potential to improve the quality of the research and lend nuance to its findings. The wise scholar, then, would want to take such feedback - feedback that promotes a potentially productive shift in vantage points - seriously.

Here again, paying attention to the opinion of the general academic public can be valuable, as it promotes humility, invites a knowledge-seeking posture, and helps scholars avoid the trappings of intellectual arrogance. But, just as we do not want civility to drift into uncritical conformity, we do not want humility to slip into uncritical deference to the dominant opinion within the academy. A well-developed impartial spectator, armed with a practiced habit of self-command, helps us maintain a healthy degree of intellectual and emotional independence. Navigating this terrain, however, can be particularly challenging when the academic public issues feedback that is accusatory in tone, fevered in its pitch, or exaggerated by ideological faction.

Smith notes that when we are accused, we often feel a sense of doubt even if we know we have harbored no malevolent intent. The clamor and vehemence can give even the most seasoned professional pause. In such circumstances,

the man within seems sometimes, as it were, astonished and confounded by the vehemence and clamour of the man without [the general public]. The violence and loudness with which blame is sometimes poured out

\footnotetext{
$\overline{18}$ Arguably, this is true in the natural sciences and engineering as well. The questions that do and not occur to the researcher, for example, can be driven by the researcher's cultural, social, or economic position in society. For a discussion of the potential ways in which culture informs the development of the impartial spectator, see Storr and John (2015).

19 On this point, see Smith's (TMS, Part I, Section I, Chapter 3) discussion of the pronounced grief some people may exhibit at the passing of a particular person. Though we may not feel the same degree of pronounced grief, we understand and have sympathy with, say, the deceased man's son who does exhibit such emotion. We close the gap by imagining ourselves in the grieving man's shoes. Further, throughout TMS, Smith points to the value of reading history and works of literature in order to extend our moral imagination beyond what we can experience directly.
}

upon us, seems to stupify and benumb our natural sense of praiseworthiness and blameworthiness; and the judgments of the man within [are] so much shaken in the steadiness and firmness of their decision, that their natural effect, in securing the tranquility of the mind, is frequently, in a great measure, destroyed. We scarce dare to absolve ourselves, when all our brethren appear loudly to condemn us. The supposed impartial spectator of our conduct seems to give his opinion in our favour with fear and hesitation; when that of all the real spectators, when that of all those with whose eyes and from whose station he endeavours to consider it, is unanimously and violently against us (TMS 228).

In the face of vehemence and clamor, it may be difficult for a scholar to sort out whether the academic public's heightened sensibility is a robust signal that her written or spoken statements are seriously misguided, or merely the noise of faction, or some combination of the two. The doubt that comes with clamor may indeed give the scholar reason to examine her conduct with particular care, taking the time to explore from different vantage points, for example, before issuing further comment. Such a pause, even if temporary, is a form of selfcensorship that may be warranted if, for example, it means closing a critical knowledge gap.

Smith notes, however, that factions can corrupt public opinion to the point that it is no longer a source of reliable counsel. If we receive censure from the public, "either for actions which we never performed, or for motives which had no influence upon those which we may have performed," we must rely on the impartial spectator (or our best estimation of it) to render the correct judgment, "and assure us, that we are by no means the proper objects of censure which has so unjustly been bestowed upon us" (TMS 227-8). The experienced scholar might care what another colleague thinksperhaps as confirmation of what she has gleaned from her internal dialogue with her impartial spectator-but it will matter who that colleague is. As Smith notes, "To a real wise man, the judicious and well-weighed approbation of a single wise man gives more heartfelt satisfaction than all the noisy applauses of ten thousand ignorant though enthusiastic admirers" (TMS 409). Or in other words, if there is any doubt about whether one has understood the impartial spectator's judgment correctly, the wise scholar will consult an actual colleague with a reputation for impartiality and wisdom before uncritically accepting the judgment of the general academic public. $^{20}$

\footnotetext{
${ }^{20}$ Arguably, in addition to impartiality and wisdom, the sincere but selfdoubting scholar would want to seek out a colleague who possesses a vantage point/life-experience different from her own so that she might gain insight on what may be lingering in her intellectual blind spots.
} 
Smith notes that it takes a "certain intrepidity, a certain firmness of nerves and hardiness of constitution" to do what is right, and that we build this intrepid firmness through experience (TMS 398). Factions and war, he observes, are good training grounds, as they are, in Smith's view, "the best schools for forming every man to this hardiness and firmness of temper, [and] they are the best remedies for curing him of the opposite weakness..." (TMS 398). Ultimately, though, it is not a firmness of temper that ensures that we follow through on what we have determined to be the right course of action. It is our respect for our own dignity that keeps us on the right course.

The man who feels the full distress of the calamity which has befallen him, who feels the whole baseness of the injustice which has been done to him, but who feels still more strongly what the dignity of his own character requires; who does not abandon himself to the guidance of the undisciplined passions which his situation might naturally inspire; but who governs his whole behavior and conduct according to those restrained and corrected emotions which the great inmate, the great demigod within the breast prescribes and approves of; is alone the real man of virtue, the only real and proper object of love, respect, and admiration (TMS 397). ${ }^{21}$

To sum up, commonplace tensions in academic life give us a training ground in which we develop our impartial spectator to the point where we can also manage the epistemological and moral challenges of admonitions, accusations, and weaponized abrasion. As a scholar's impartial spectator develops, she is able to mine feedback coming from the academic public that can close knowledge gaps and lend insight to her work. But the development of a mature impartial spectator also means that the scholar is able to gain both intellectual and emotional distance from the general academic public, placing less weight on its opinion where appropriate. This advanced developmental stage of an impartial spectator allows us to "be more indifferent about the applause, and, in some measure, despise the censure of the world; secure that, however misunderstood or misrepresented, we are the natural and proper objects of approbation" (TMS, 206).

\footnotetext{
${ }^{21}$ It may be objected that we have a strong incentive to deceive ourselves into thinking that the impartial spectator is truly impartial, allowing us to believe that we are on the right moral track when in fact we are not. There is no Archimedean point - free of any possible partiality - that guarantees that the impartial spectator has fully matured and perfectly calibrated. But Smith's moral theory is not alone in this regard. No moral theory applicable to the world in which we live is able to purchase moral perfection. Smith's theory describes instead a learning processes that, through practice, steers us in the right direction.
}

\section{The Implications for Teaching, Learning, and Mentoring}

The liberal intellectual tradition both celebrates associational life and warns of its dangers. Associational life is the source of general rules that make complex social order possible. It is also the source of a velvet-gloved tyranny that, if left unchallenged, dulls our minds and dampens the quality of inquiry and discourse. The dual nature of associational life is as present in the academy as in any other social environment, perhaps more so. The life of the mind is intimately connected to the community of scholars with whom we associate. To be cut off from or threatened by that community can be emotionally and professionally devastating. But if the fear of being cut off leads to uncritical conformity and deference, the core meaning of our work as members of the academic community is in danger of being lost. Here, I have argued that in his discussions of the impartial spectator and self-command, Smith offers contemporary scholars guidance for how to navigate the epistemological and moral challenges of associational life within the academy.

Smith's account of the impartial spectator is a developmental story. With experience, an impartial spectator matures in its ability to take on increasingly difficult epistemological and moral challenges. Experience matters in our ability to discern whether the self-censorship decision is being driven by public opinion and its trappings (desire for praise, fear of blame) or by the motivations of a well-developed impartial spectator (desire to do what is praiseworthy and to avoid that which is blameworthy). An impartial spectator develops precisely because we imagine how our conduct and passions appear to others out there in the world, but develops even further as we learn to maintain some degree of separateness and independence with respect to associational life. The judgment of a well-developed impartial spectator, then, is capable of being simultaneously sensitive to and resilient against the sentiments of others.

Smith was clear that in developing one's ability to successfully engage the impartial spectator, age and experience matter. "Persons of an advanced age, whom long experience of the folly and injustice of the world has taught to pay little regard either to its censure or to its applause, neglect and despise obloquy, and do not even deign to honour its futile authors with any serious resentment" (TMS 243). While Smith applauds the independent mind that is able to ignore undeserved censure, he also issues a caution to those who are less experienced at navigating such terrain. "This indifference, which is founded altogether on a firm confidence in their own well-tried and well-established characters, would be disagreeable in young people, who neither can nor ought to have any 
such confidence" (TMS 243-4). It is not clear how Smith is defining "young people," but he suggests that we should not expect wisdom from anyone under the age of forty. ${ }^{22}$

Whether we agree or disagree with Smith on the precise point we might expect wisdom, there is something to his point that none of us arrives on the scene of academic or public discourse fully formed. This renders weaponized abrasion a particularly harmful form of feedback. When intellectual challenge becomes less "engaging and coaching" and more a game of spotting and punishing the potential heretic, inexperienced scholars, be they undergraduates or newly minted PhDs, are particularly vulnerable. Some will be unfairly demonized. The rest will internalize the lesson emerging from such demonization as "it's best to keep my mouth shut." Further, the current age, which exposes youthful mistakes to the harsh gaze of social media audiences, exacerbates the problem, as it no longer affords less-experienced scholars the space to make mistakes locally, among friends, and on a small scale. Again, the impulse to retreat to the comforts of selfcensorship is understandable.

But if scholars are to gain both the polish and civility that mild abrasion affords and the intellectual and emotional independence academic discourse requires, the academic community will need to be more deliberate about how we cultivate these values with our students, with our colleagues, and within ourselves. We must, in other words, re-invigorate the liberal tradition that underlies higher education - the tradition that promotes the principles of abrasion and civility but cautions against distorted versions of these principles that undermine the intellectual enterprise. This liberal tradition may be modeled through debate and discussion, but special emphasis has to be placed on how a scholar is to engage in debate and discussion if she is to advance rather than shut down discourse that leads to the growth of knowledge. An emphasis on the ethical principles of the conversation-principles such as epistemic humility, a posture of sympathetic listening, and a commitment to entering the conversation in good faith - can no longer simply be assumed. These principles need to be a deliberate part of inducting new scholars into the traditions of the liberal academy.

Given the pace and trajectory of technological change in online discourse and increased divisiveness in the body politic, the incentives to engage in fear-induced self-censorship are not likely to wane, and neither are its damaging effects without deliberate effort on the part of scholars willing to champion the principles of the liberal academy. Insisting that scholars simply adopt the steely resolve they

\footnotetext{
${ }^{22}$ Smith counsels, "Though your son under five-and-twenty years of age should be but a coxcomb, do not upon that account despair of his belonging before he is forty a very wise and worthy man, and a real proficient in all those talents and virtues to which at present he may only be an ostentatious and empty pretender" (TMS 416-7).
}

need to speak out at any cost is inadequate. Addressing the problem will require a cultural shift within the academy in which scholars at every level of development are expected to refine their ability to discern which moments call for sympathetic listening, greater humility, and a posture of knowledge-seeking, and which call for greater resilience against the dominant perspective of the general academic public. For this cultural shift to take hold, learning how to coach and mentor less-experienced scholars toward the intellectual and moral habits of a welldeveloped impartial spectator must become a deliberate part of the teaching and learning process, for the undergraduate seeking to become a liberally educated person, for the graduate student seeking to enter the professional life of the academy, and for the experienced scholar seeking to secure the future of the liberal academy.

Acknowledgements I wish to thank Shane Courtland, Ramon Degennaro, Andrew J. Cohen, Thomas Cushman, Samuel Gill, Bradley Jackson, Daniel Klein, James Otteson, Michael Tolhurst, Sean Stevens, Virgil Storr, and Jonathan Zimmerman for their comments on an earlier draft and their insights on Smith and the ethical challenges of contemporary academic discourse. The usual caveat applies.

Open Access This article is distributed under the terms of the Creative Commons Attribution 4.0 International License (http:// creativecommons.org/licenses/by/4.0/), which permits unrestricted use, distribution, and reproduction in any medium, provided you give appropriate credit to the original author(s) and the source, provide a link to the Creative Commons license, and indicate if changes were made.

\section{Further Reading}

Bar-Tal, D. 2017. Self-Censorship as a Socio-Political-Psychological Phenomenon: Conception and Research. Political Psychology, 38(supplement 1), 37-65.

Blackford, R. 2019. The Tyranny of Opinion: Conformity and the Future of Liberalism. New York:Bloomsbury Academic.

Bromwich, D. 2016. What we are allowed to say. London Review of Books, 38(18), 3-10.

Chamlee-Wright, E. 2018. Governing Campus Speech: A Bottom-up Approach. Society, 55(5), 392-402.

Collins, R. 2002. On the Acrimoniousness of Intellectual Disputes. Common Knowledge, 8(1), 47-70.

Courtland, S. 2018. The Necessity of Offense, the Value and Limits of Academic Speech: Philosophical, Political, and Legal Perspectives, In D. A. Downs and Christopher Surprenant (Eds.), Routledge: 15566.

Courtland, S. Forthcoming. Advocate for the Devil.

de Tocqueville, Alexis. 1835 [2010]. Democracy in America, Volumes I and II, Indianapolis: Liberty Fund.

Dreger, A. 2016. Galileo's Middle Finger: Heretics, Activists, and One Scholar's Search for Justice. New York:Penguin Books.

Glynn, C. J., Hayes, A. F., \& Shanahan, J. E. 1997. Perceived Support for One's Opinions and Willingness to Speak Out: A Meta-analysis of Survey Studies on the "Spiral of Silence". Public Opinion Quarterly, 61, 452-461.

Hayes, A. F., \& Matthes, J. 2017. Self-censorship, the Spiral of Silence, and Contemporary Political Communication. In K. Kenski, \& K. H. 
Jamieson (Eds.), The Oxford Handbook of Political Communication. Oxford: Oxford University Press. https://doi.org/ 10.1093/oxfordhb/9780199793471.013.31.

Hayes, A. F., Matthes, J., \& Eveland Jr., W. P. 2013. Stimulating the Quasi-statistical Organ: Fear of Social Isolation Motivates the Quest for Knowledge of the Opinion Climate. Communication Research, 40, 439-462.

Hyde, C. A., \& Ruth, B. J. 2002. Multicultural Content and Class Participation: Do Students Self-censor? Journal of Social Work Education, 38, 241-256.

Kipnis, L. 2017. Unwanted Advances: Sexual Paranoia Comes to Campus. New York:Harper Collins.

Klein, D.B., Matson, E.W., and C. Doran. 2018. The Man Within the Breast, the Supreme Impartial Spectator, and Other Impartial Spectators in Adam Smith's. The Theory of Moral Sentiments, History of European Ideas, 44(8): 1153-1168.

Lilla, M. 2016. The End of Identity Liberalism. New York Times, November 18. Online: https:/www.nytimes.com/2016/11/20/ opinion/sunday/the-end-of-identity-liberalism.html?_r=0 (Accessed March 8, 2919).

Loury, G. 1994. Self-Censorship in Public Discourse: A Theory of 'Political Correctness' and Related Phenomena. Rationality and Society, 6(4), 428-461.

Mill, J.S. 1956 [1859]. On Liberty, Indianapolis: Bobbs-Merrill.

Noelle-Neumann, E. 1974. The Spiral of Silence: A Theory of Public Opinion. Journal of Communication, 24, 43-51.

Oakeshott, M. 1951. The Voice of Liberal Learning. Indianapolis:Liberty Fund.

Otteson, J. 2002. Adam Smith's Marketplace of Life. New York: Cambridge University Press.

Paganelli, M. P. 2010. The Moralizing Role of Distance in Adam Smith: The Theory of Moral Sentiments as Possible Praise of Commerce. History of Political Economy, 42(3), 425-441.

Rauch, Jonathan. 2013 [1993]. Kindly Inquisitors: The New Attacks on Free Thought, Chicago: University of Chicago Press.

Shields, J., \& Dunn, J. 2016. Passing on the Right: Conservative Professors in the Progressive University. Oxford:Oxford University Press.
Shils, E. 1997a. The Virtue of Civility: Selected Essays on Liberalism, Tradition, and Civil Society. Indianapolis:Liberty Fund.

Shils, E. 1997b. The Calling of Education: The Academic Ethic and Other Essays on Higher Education. Chicago:University of Chicago Press.

Smith, Adam. 1976 [1759]. The Theory of Moral Sentiments, Indianapolis: Liberty Fund.

Stevens, S. T., Lee, J., Anglin, S. M., Contrada, R., Welch, C. A., Labrecque, J. S., Motyl, M., Duarte, J., Terbeck, S., Sowden, W., Edlund, J., \& Keith Campbel, W. 2018. Political Exclusion and Discrimination in Social Psychology: Lived Experiences and Solutions. In J. T. Crawford, \& L. Jussim (Eds.), The Politics of Social Psychology (pp. 210-244). New York: Routledge.

Storr, V. H., \& John, A. 2015. The Impartial Spectator's Cultural Spectacles. In C. Thomas (Ed.), Of Sympathy and Selfishness: The Moral and Political Philosophy of Adam Smith. Macon: Mercer University Press.

Strossen, Nadine. 2018. Hate: Why We Should Resist It with Free Speech, Not Censorship, Oxford: Oxford University Press.

Weinstein, J. R. 2013. Adam Smith's Pluralism: Rationality, Education, and the Moral Sentiments. New Haven:Yale University Press.

Wood Ion, H. 2015. The Essential Role of Abrasion in Developing Healthy Institutions of Liberal Learning. In E. Chamlee-Wright (Ed.), Liberal Learning and the Art of Self-Governance. New York: Routledge.

Publisher's Note Springer Nature remains neutral with regard to jurisdictional claims in published maps and institutional affiliations.

Emily Chamlee-Wright is President and CEO of the Institute for Humane Studies at George Mason University. Her feature article, "Governing Campus Speech: A Bottom-up Approach" appeared in Society, Vol. 55, No. 5, September/October 2018. 